\title{
Pengembangan Smart Application Translation Aneka Bahasa Sulawesi Berbasis Android
}

\author{
Andi Maslan1,*, Yana Setiono ${ }^{1}$, Faizal Alfazri 1 \\ 1 Universitas Putera Batam \\ (cooresponding author) lanmasmasco@gmail.com*)
}

\begin{abstract}
The Indonesian people have diverse tribes. Similarly, the regional language that is widespread in Indonesia, each of the tribes in Indonesia have different languages included in South Sulawesi. The number of local and foreign travelers to visit tourist attractions in the city, so that will indirectly communicate with the locals at the time of tourist visits. This research aims to develop smart applications translators Indonesian to Sulawesi region based on Android. This application can translate the three regional languages, namely the language Konjo, makasar and Bugis. The method used is research development by using the Linear Sequential Model. Applications can run well and have gone through the testing phase by inserting a vocabulary of 100 vocabularies for each language area. So that these applications can be used by people in Indonesia who can get through the Google Play Store.
\end{abstract}

Keyword : Application, Interpreter, Android, JSON

Intisari- Indonesia memiliki banyak suku, sehingga banyak bahasa daerah. Untuk memudahkan dalam komunikasi maka diperlukan Aplikasi penterjemah bahasa Indonesia ke bahasa daerah khususnya Sulawesi Selatan. Di Sulawesi Selatan memiliki beraneka ragam bahasa yaitu bahasa Makasar, Konjo, dan Bugis. Pada saat wisatawan local berkunjung ke daerah Sulawesi maka diperlukan aplikasi yang dapat menterjmahkan dari bahasa Indonesia ke Bahasa Daerah tersebut. Untuk mengembangkan aplikasi ini digunakan Linear Sequential Model, untuk memudahkan proses pengembangan. Setelah melalui tahap pengembangan maka aplikasi ini telah berjalan dengan baik dengan melalui proses pengujian, sehingga aplikasi Translator Indonesia - Sulawesi ini sudah dapat di akses melalui Google Play Store.

Kata Kunci : Aplikasi, Penterjemah, Android, JSON

\section{PENDAHULUAN}

Perkembangan teknologi informasi saat ini semakin berkembang, berbagai aplikasi sudah tercipta untuk digunakan diberbagai kegiatan bisnis. Salah satu aplikasi yang banyak digunakan adalah aplikasi yang berbasis android. Aplikasi android merupakan aplikasi open source yang dikembangkan oleh Google Corporation. Banyak inovasi yang telah dikembangkan oleh perusahaan tersebut mulai dari aplikasi e-commerce, mesin pencari sampai dengan system operasi bahkan memiliki aplikasi penterjemah berbagai bahasa yang ada di Dunia yang dikenal dengan google translate. Dengan berpedoman pada aplikasi penterjemah bahasa yang sudah ada, maka saat ini google belum dapat mengimplementasikan bahasa perterjemah menggunakan bahasa daerah, yang ada hanya kamus bahasa daerah yang telah di implementasikan dan sudah dapat download melalui system operasi berbasis android. Pengembangan aplikasi kamus mobile yang berfokus pada smartphone android diantaranya Aplikasi Mobile Kamus Bahasa Indonesia, Aplikasi Kamus Sunda, Aplikasi Kamus Bahasa Indonesia-Jawa, Kamus Nusantara, terdiri dari empat bahasa Jawa, Sunda, Banjar dan Minang tersedia di Google Play Store, dan masih banyak yang lainnya [5]. Penggunaan bahasa daerah telah mengalami penurunan penggunaan dalam bahasa komunikasi keseharian. Hal ini terlihat dari kebiasaan generasi muda yang lebih suka berkomunikasi dengan bahasa gaul atau alay dari pada bahasa daerah yang mereka gunakan. Melestarikan bahasa daerah dirasa perlu ditengah perkembangan teknologi yang semakin pesat. Media penterjemah dapat menjadi solusi untuk mengenalkan beragam bahasa daerah yang ada di Indonesia.

Teknologi smartphone dengan sistem operasi android menawarkan berbagai fitur layanan aplikasi yang sangat banyak di Google Play Store. Aplikasi yang terdapat pada play store memungkinkan pengguna untuk menginstall berbagai aplikasi yang dibutuhkan pengguna termasuk aplikasi penterjemah kalimat. Aplikasi pentermah ini juga berguna bagi para wisatawan local ataupun manca Negara yang melakukan kunjungan ke tempat wisata yang ada di Indonesia. Karena tempat wisata yang ada di Indonesia memiliki keanekaragaman budaya, sehingga masing-masing tempat memiliki ciri bahasa yang berbeda. Dari permasalahan ini maka perlu dikembangkan atau di racang aplikasi Smart Application Translation Bahasa Daerah Sulawesi Berbasis Android dengan tujuan untuk menghasilkan aplikasi yang dapat di akses melalui playstore dan dapat digunakan oleh para wisatawan yang berkunjung ke suatu daerah khusus daerah Sulawesi. 


\section{KAJIAN LITERATUR}

\section{A. Bahasa}

Bahasa merupakan fenomena yang rumit yang melibatkan proses pengenalan bunyi, sintaksis kalimat serta inferensi semantik tingkat tinggi. Bahasa adalah penggunaan kode yang merupakan gabungan fonem sehingga membentuk kata dengan aturan sintaks untuk membentuk kalimat yang memiliki arti [7]. Pada dasarnya, bahasa mempunyai fungsi-fungsi tertentu yang digunakan berdasarkan seseorang, yaitu sebagai alat untuk mengekspresikan diri, sebagai alat untuk komunikasi, sebagai alat untuk mengadakan integrasi dan beradaptasi sosial pada lingkungan atau situasi tertentu, dan sebagai alat kontrol sosisal.

Android adalah nama software yang dipakai pada perangkat mobile yang mencakup berbagai komponen yaitu system operasi, middleware dan aplikasi kunci yang di rilis oleh Google [6]. Android mencakup keseluruhan aplikasi mulai dari system operasi hingga pengembangan aplikasi itu sendiri. Platform pengembangan aplikasi android yagn merupakan bagian dari android memiliki lisensi open source atau terbuka sehingga dapat membangun aplikasi yang kaya dan inovatif.

\section{B. Pengembangan Aplikasi}

Untuk melakukan pengembangan aplikasi berbasis android maka harus dibangun terlebih dahulu sebuah web service yang bisa menghubungkan antara server dengan yang dibuat. Ada dua format yang biasa digunakan dalam pertakaran data antara web server dengan aplikasi android yatiu JSON dan XML. Performanca JSON lebih cepat dibanding dengan XML [9]. Hal ini disebabkan karena JSON adalah sebuah format pertukaran data yang ringan berbasis teks, dan tidak tergantung pada bahasa. JSON dapat digunakan sebagai salah satu format untuk pertukaran data melalui internet.

Menurut Pressman (2010, p841) Unified Modeling Language (UML) adalah suatu standar bahasa yang digunakan untuk memvisualisasikan, menspesifikasikan, mengkonstruksikan, serta mendokumentasikan sebuah sistem software [11]. Lethbridge (2010, p169) Unified Modelling Language (UML). UML yaitu standar untuk bahasa grafis dalam pemodelan software yang berorientasi objek. Dikembangkan oleh James Rumbaugh, Grady Booch, dan Ivaar Jacobson pada tahun 1990an dengan notasi mereka masing-masing yang kemudian UML akhirnya diresmikan sebagai sebuah standar pemodelan objek oleh Object Management Group[11].

\section{Database}

Menurut Jay A.Kreibich (2010, p12) SQLite adalah paketan perangkat lunak bersifat public domain yang menyediakan sistem untuk melakukan manajemen basis data relasional aau RDBMS. Kemudian sistem basis data relasional tersebut melakukan proses untuk penyimpanan record yang telah terdefinisi pengguna untuk ukuran serta proses intruksi perintah query yang kompleks dan penggabungan data berbagai tabel yang akan mendokumentasi laporan dalam bentuk rangkuman data. Istilah dari kata "Lite" pada SQLite menunjukkan pada sifat dari SQLite, yang ringan saat dihubungkan atau melakukan pengaturan, administrative overhead, dan pemakaian sumber[11].

\section{METODE PENELITIAN}

Sistem yang di rancang ini menggunakan metode Linear Sequential Model, model ini adalah melakukan pendekatan secara sistematis dan urut mulai dari level kebutuhan sistem lalu menuju ke tahap analisis, desain, coding, testing / verification, dan maintenance[12]. Disebut dengan waterfall karena tahap demi tahap yang dilalui harus menunggu selesainya tahap sebelumnya dan berjalan berurutan. Sebagai contoh tahap desain harus menunggu selesainya tahap sebelumnya yaitu tahap requirement[15].

\section{A. Kebutuhan Perancangan Aplikasi}

Rekaysa Smart Application Translation Bahasa Daerah Berbasis Android ini akan dibuat berdasarkan permodelan UML yang berorientasi objek [10]. Rekayasa ini adalah himpunan struktur dan teknik untuk pemodelan desain program berorientasi objek

\section{B. Arsitektur Pengembangan Aplikasi}

Untuk memudahkan dalam proses rekayasa pada palikasi ini maka berikut proses gambaran penggunaan aplikasi yang dapat dlihat sebagai berikut : 


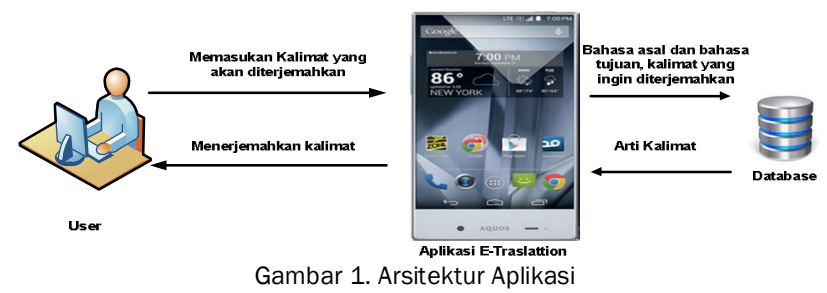

\section{Analisis Dan Perancangan}

Berdasarkan analisis kebutuhan system yang telah diuraikan pada metode penelitian maka Analisis dan perancangan aplikasi Smart Translation melalui tahap perancangan sebagai berikut :

\section{1) Use Case Diagram}

Use case diagram adalah gambaran graphical dari beberapa atau semua actor, use case, dan interaksi diantara komponen-komponen tersebut yang memperkenalkan suatu sistem yang akan dibangun digunakan untuk menjelaskan bagaimana langkah-langkah yang seharusnya dikerjakan oleh sistem. Use case diagram menjelaskan manfaat suatu sistem jika dilihat menurut pandangan orang yang berada di luar sistem. Diagram ini menunjukkan fungsionalitas suatu sistem atau kelas dan bagaimana sistem tersebut berinteraksi dengan dunia luar[10]. Adapaun use case pada aplikasi ini adalah sebagai berikut :

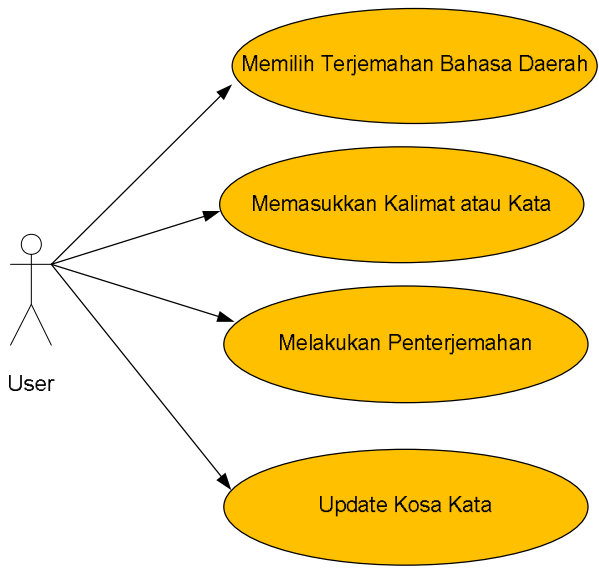

Gambar 2. Use Case Diagram

Dari Use case diagram diatas dapat dijelaskan bahwa pengguna aplikasi melakukan pemilihan bahasa daerah sulawesi yaitu Bugis, Makasar dan Konjo, setelah melakukan pemilihan bahasa daerah yang akan diterjemahkan maka selanjutnya memasukan kalimat atau kata yang akan ditermahkan, lalu proses terakhir melakukan penterjemahan untuk mendapatkan hasil terjemahan.

\section{2) Class Digram}

Selanjutnya untuk menampilkan kosa kata dan hasil terjemahan pada smart tranlation Indonesia - Sulawesi maka digunakan relasi antar tabel yang tertuang dalam diagram clas. Diagram class menjelaskan jenis-jenis objek-objek dalam system dan berbagai macam hubungan atau relasi yang tetap yang terdapat diantara tabel-tabel yang tersedia dalam database, berikut objek tersebut: 


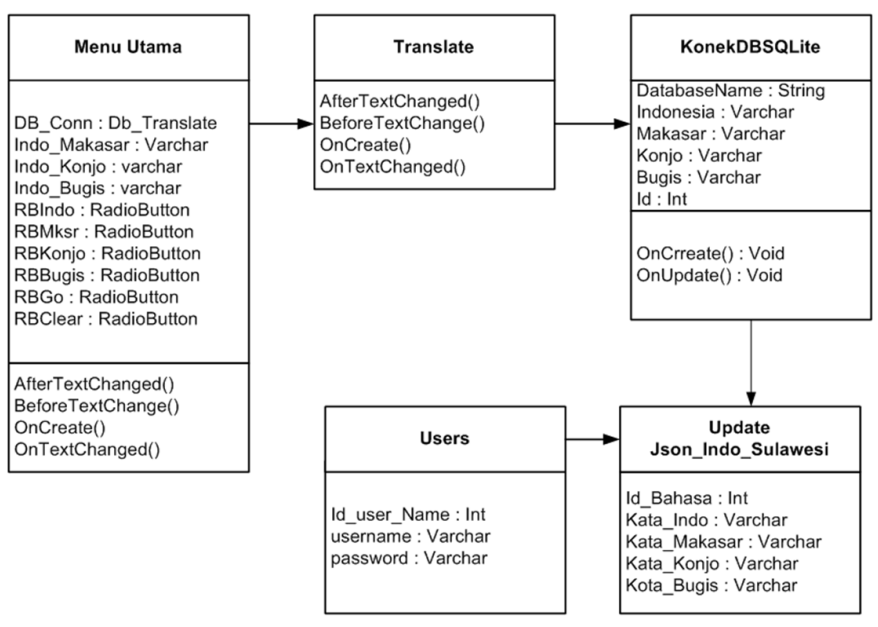

Gambar 3. Class Diagram

3) Squence Diagram

Untuk melihat urutan proses bahasa penterjeman Indonesia $\rightarrow$ Sulawesi maka diperlukan diagram sequence, untuk user atau admin yang melakukan penterjemahan kata atau kalimat. Proses diawali dengan user memilih fitur terjemahan bahasa daerah, lalu memilih bahasa konjo, atau bulukumba atau makasar. Setelah pilihan sudah sesuai maka user memasukkan kata atau kalimat lalu ditermahkan oleh user lalu user dapat melakukan update kosa kata. Semua kata yang diterjemahkan diambil dari database yang telah tersedia pada aplikasi. Berikut Urutan Squence Diagram rancangan aplikasi tersebut.

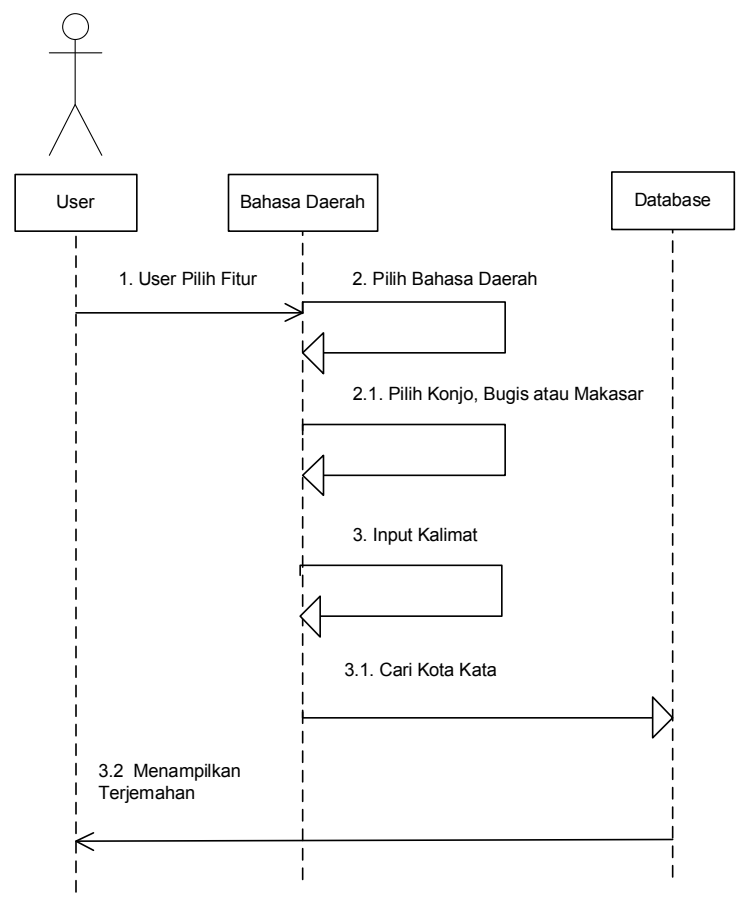

Gambar 4. Squence Diagram 


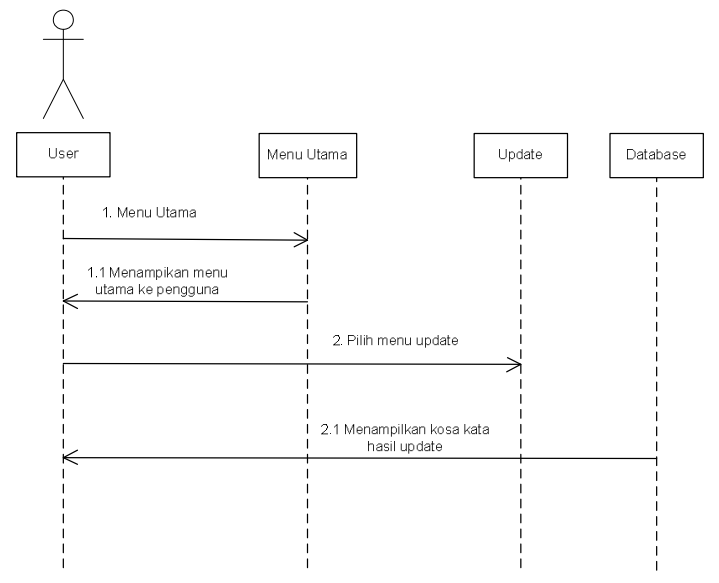

Gambar 5. Squence Diagram Update Kosa Kata

4) Aktiviti Diagram

Diagram aktiviti ini menjelaskan cara user untuk menggunakan aplikasi penterjemah ini, dan semua aktivitas-aktivitas yang dilakukan oleh user dijabarkan secara detail yang dapat dilihat dari hasil rancangan sebagai berikut :

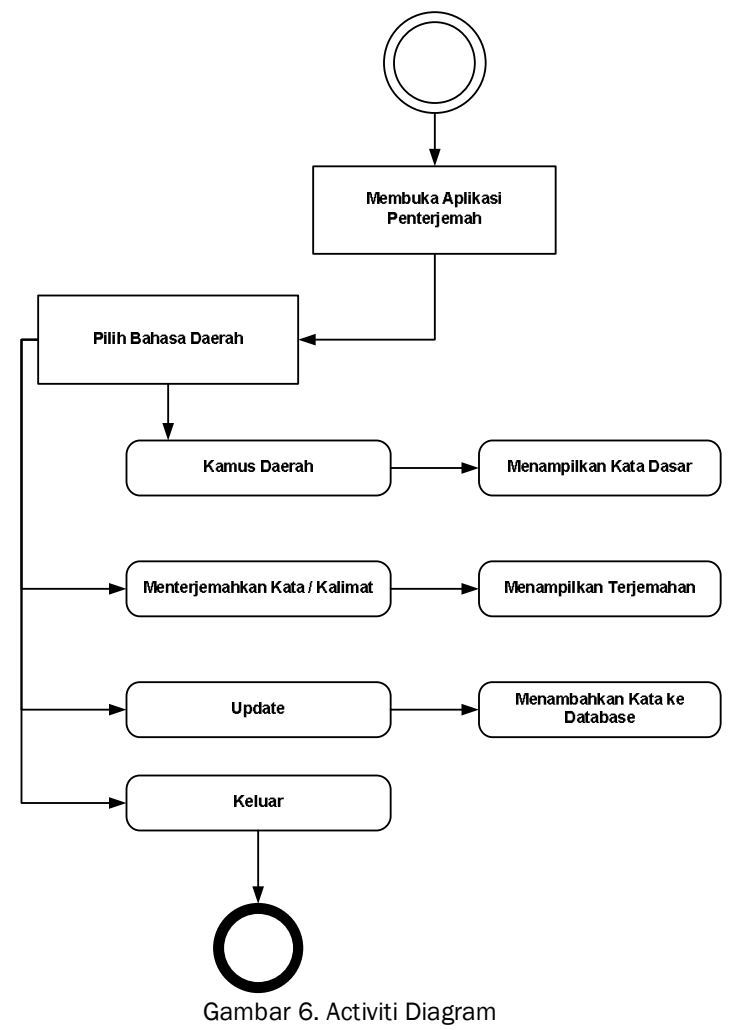

D. Perancangan User Interface

Perancangan tampilan ini akan ditampilkan rancangan interface dari awal eksekusi program hingga menampilkan hasil output yang dicari. Adapun rancangan tampilan pada aplikasi ini adalah sebagai berikut : 


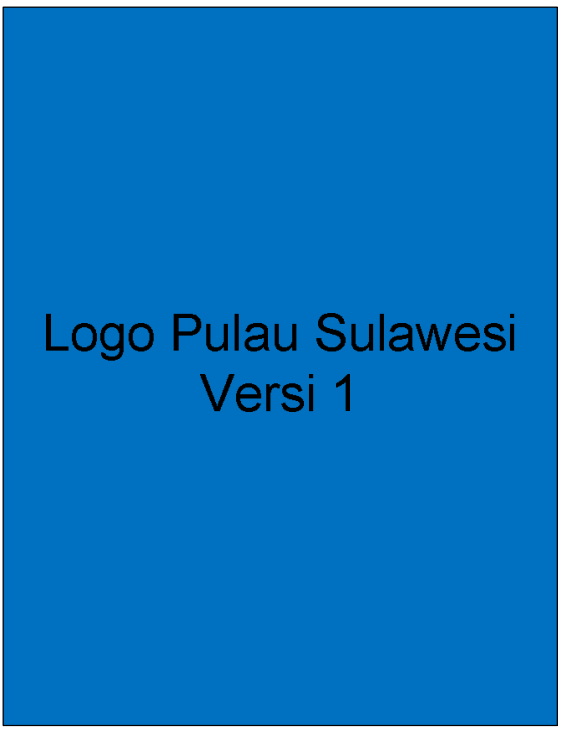

Gambar 7. Tampilan Awal

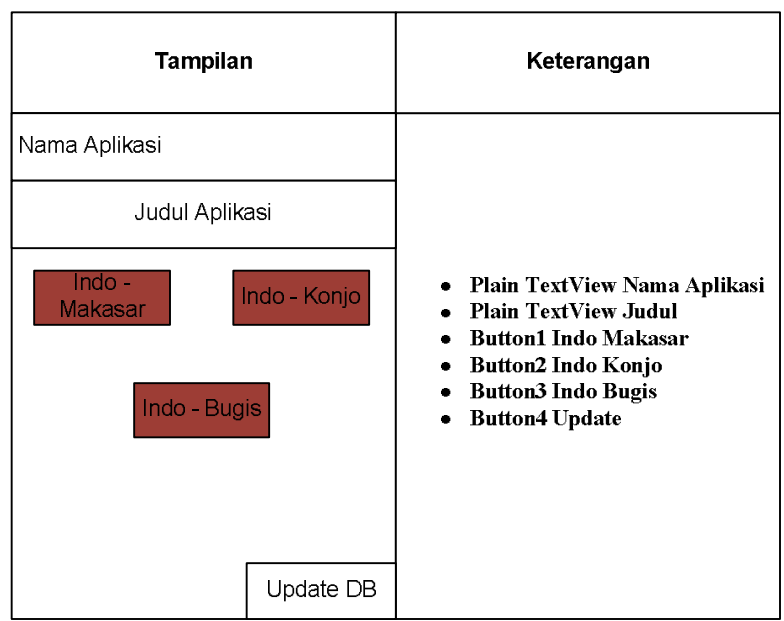

Gambar 8. Rancangan Halaman Tampilan Jenis Bahasa Daerah 


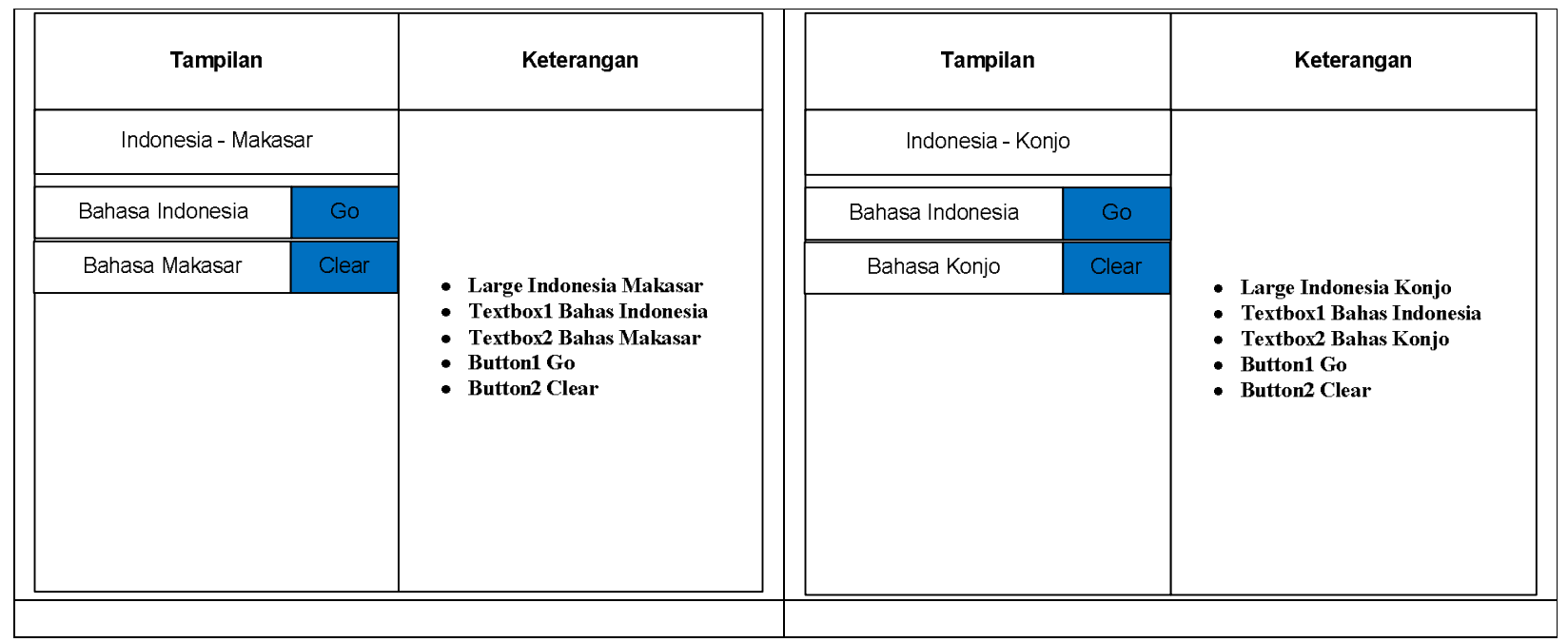

Gambar 9. Tampilan penterjemah Indonesia Makasar dan Konjo

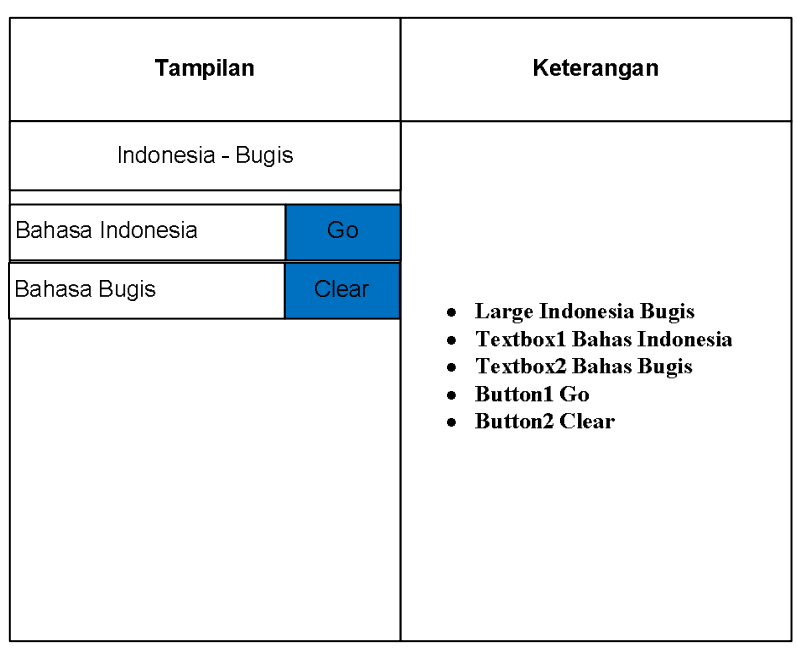

Gambar 10. Tampilan penterjemah Indonesia Bugis

\section{E. Perancangan Update Database}

Untuk melakukan apdate database ke Aplikasi SmartTranlator yang ada di Android, maka diperlukan database service. Database service yang ada ini akan melakukan Generate database ke JSON agar mudah digunakan sebagai salah satu format untuk pertukaran data melalui internet.



Gambar 11. Form Login Update Database 


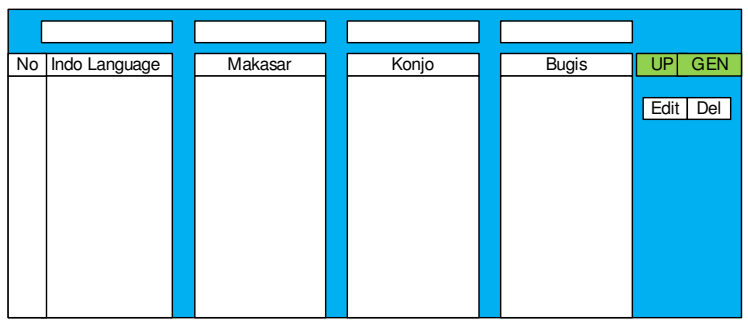

Gambar 12. Form Input Kosa Kata dan Generate Kosa kata ke System Android

\section{Implementasi Pembuatan Program}

Aplikasi smart Translation bahasa Indonesia ke Bahasa Sulawesi ini dijalankan melalui Genymotion emulator adalah sebagai berikut :

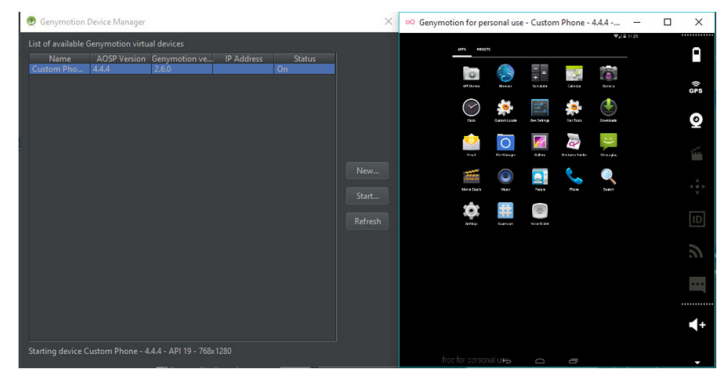

Gambar 13. Tampilan awal AVD ( Android Virtual Device )

Di dalam tampilan awal AVD ( Android Virtual Device ) ini dibagi menjadi dua bagian, bagian di sebelah kiri sebagai layar untuk menampilkan dan sedangkan bagian kanan adalah layar control serta input keyboard. Dari emulator tersebut semua proses coding dari pemrogram android studio dapat dilihat secara langsung tampilan aplikasi ini. Tampilan yang telah dibuat sesuai dengan rancangan pada bab sebelumnya dapat dilihat sebagai berikut :

1) Tampilan Awal (Splash)

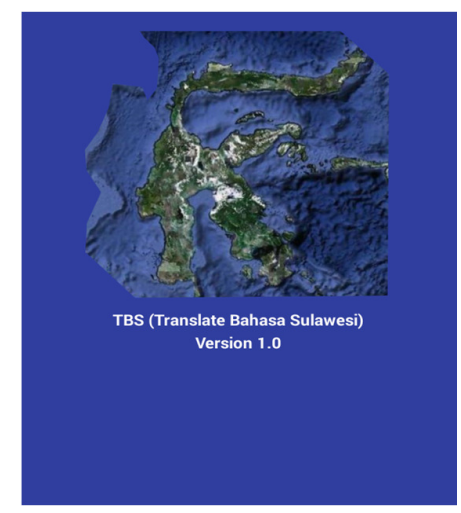

Gambar 14. Tampilan awal (Splash)

Tampilan awal (Splash) ini merupakan tampilan yang akan tampilkan jika user memilih sotcut SmartTranslator, tampilan ini hanya berdurasi 3 detik, setelah itu baru langsung menuju ke menu utama. 
2) Tampilan Menu Utama

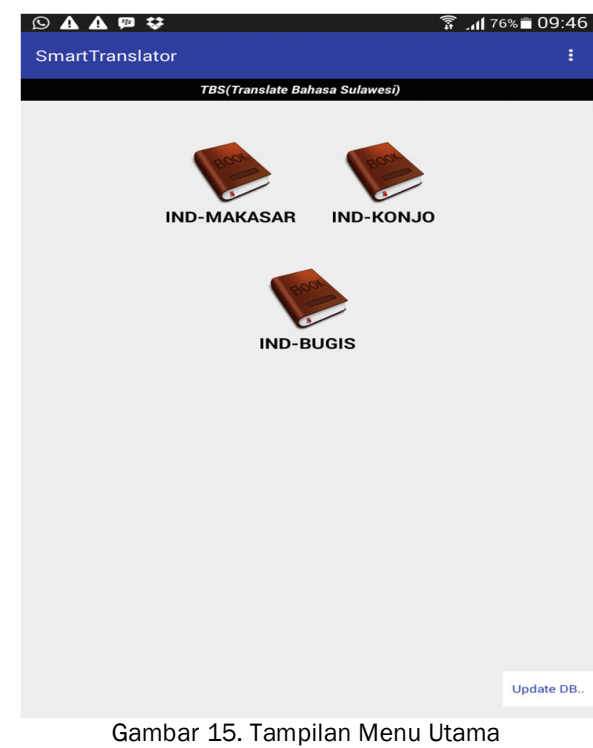

Menu utama ini terdiri dari tiga pilihan menu yang bisa di akses untuk melakukan terjemahan kata atau kalimat baik itu bahasa Indonesia ke Makasar, bahasa Indonesia ke Konjo dan bahasa indonesia ke Bugis.

3) Tampilan Penterjemahan Kalimat Indonesia ke Makasar, Konjo, dan Bugis

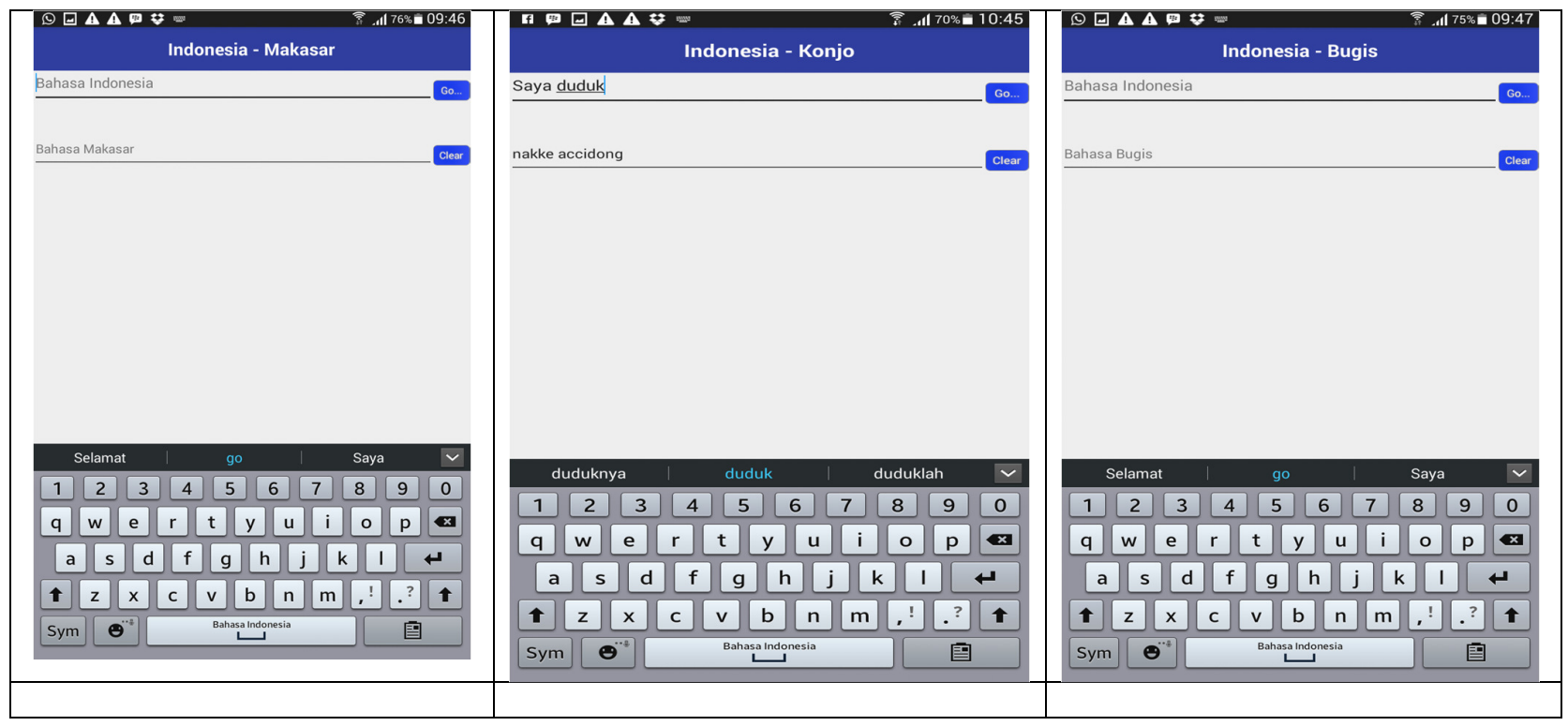

Gambar 16. Tampilan Penterjemahan Kalimat Indonesia ke Makasar

Form ini berfungsi untuk melakukan terjemahan kalimat atau kata dari bahasa indonesia ke bahasa makasar, konjo dan bugis. 
4) Form Isian Login dan Update Database

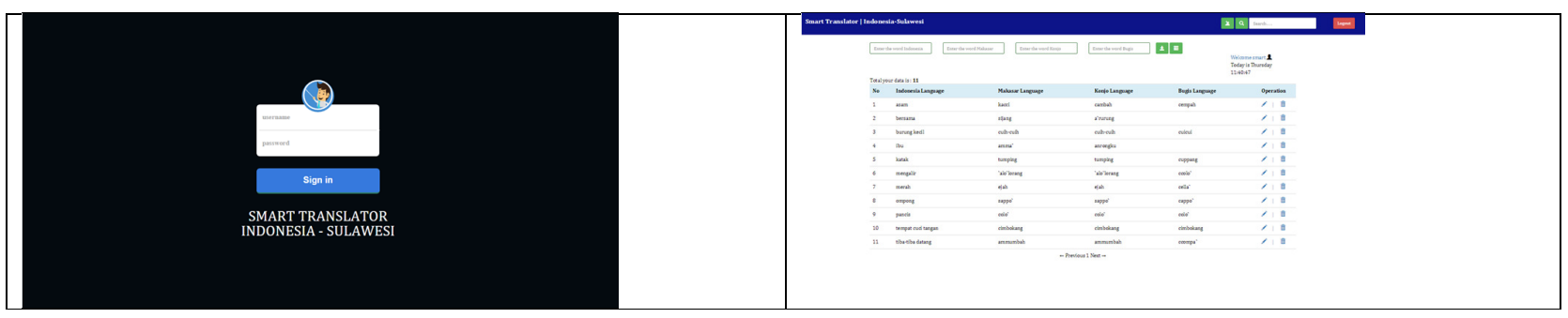

Gambar 17. Isian Login dan Update Database

Penelitian berkaitan dengan pengembangan Aplication Translation Aneka Bahasa Sulawesi Berbasis Android ini adalah Aplikasi yang di rancangan menggunakan bahasa pemrogram Android Studio dengan database SQLite, ModeL JSON untuk melakukan Generate ke Sistem Android serta Aplikasi ini dapat melakukan penterjemahan tiga bahasa daerah yaitu Indo-Makasar, Indo-Konjo dan Indo-Bugis. Aplikasi ini juga dapat digunakan secara offline dan online serta dapat di akses melalui Play Store dan memiliki kapasitas yang kecil dan ringan.

\section{REFERENSI}

[1] Abdul Kadir. 2014 Pengembangan Sistem Informasi Edisi Revisi. Andi Ofset Yogyakarta

[2] Abdul Kadir. 2010 Sistem Operasi. Edisi Revisi. Andi Ofset Yogyakarta

[3] Bambang dkk. 2013. Ilmu Sosial Budaya Dasar. Andi Yogyakarta.

[4] Dewi Soyusiawaty, Rendra Haspiyan.2009. Jurnal Aplikasi Kamus Bahasa Indonesia-Bahasa Sasak Berbasis WAP. Universitas Ahmad Dahlan

[5] Dwi Ely Kurniawan dkk. 2013. Jurnal Aplikasi Kamus Aneka Bahasa Daerah Berbasis Smartphone Android. Politeknik Negeri Batam

[6] EMS Tim. 2013. Android All In One. Elek Media Komputindo Jakarta.

[7] Edi Susilo (2012), Jurnal Aplikasi Pembelajaran Bahasa Jawa Menggunakan Bahasa Pemrograman Java Pada Platform Android. Universitas Gunadarma Depok

[8] Intan Nur Farida. Aplikasi Kamus Indonesia-Jawa Berbasis Android. Teknik Informatika, Fakultas Teknik, Universitas Nusantara PGRI Kediri

[9] Ithmam. Analisis Performa Restful Web Service dan Parser Json Menggunakan Algoritma Stream Parsing Pada Sistem Operasi Android (Studi Kasus : Sistem Informasi Laboratorium D3 Komsi Sekolah Vokasi Ugm). 2015

[10] Nugroho 2010. "Belajar UML (Unified Modeling Language). Informatika Bandung.

[11] Maulana, Aris. Pembuatan Aplikasi Kamus Antonim Bahasa Inggris Berbasis Android. Sekolah Tinggi Manajemen Informatika Dan Komputer Amikom Yogyakarta Yogyakarta. 2013

[12] Raharjo Budi. 2010. Belajar Otodidak Database MySQL Studi Kasus Toko Buku Online. Informatika Bandung

[13] Resmawan. Dkk. 2015. Pengembangan Aplikasi Kamus Dan Penerjemah Bahasa Indonesia - Bahasa Bali Menggunakan Metode Rule Based Berbasis Android. Universitas Pendidikan Ganesha Singaraja, Bali.

[14] Muhammad Fadlullah. 2012. Rancang Bangun Aplikasi Kamus Jerman Indonesia berbasis android. Universitas Stikubank (Unisbank) Semarang.

[15] Sri Dharwiyanti. 2003. Pengantar Unified Modelling Language (UML) ImuKomputer.Com. 2003. 